\title{
ECONOMICAL STUDY OF IN VIVO AND IN VITRO PROPAGATION OF RUSSELIA EQUISETIFORMIS
}

\author{
M.S. Meshaal ${ }^{*}$, K.A. Emam ${ }^{* *}$,F.Z. Ghareb ${ }^{* *}$ and E.A. Khella ${ }^{* * *}$ \\ * Department of Agricultural Economics, Fac. Agric., Cairo Univ., Giza. Egypt. \\ ** Botanical Gardens Res. Dept., Hort. Res. Inst., ARC, Giza, Egypt. \\ *** Ornamental Plants and Landscape Gardening Res. Dept., Hort. Res. Inst., ARC, Giza, Egypt.
}

ABSTRACT: This experimental trial was performed throughout two successive seasons (2015-2016) and (2016-2017) at the nursery of Horticulture Research Institute, Agricultural Research Center, Giza, Egypt. Intended to find out the effect of the individual and combined effects of different growing media with different types of propagation on morphological traits and some chemical constituents of Russelia equisetiformis Schlecht. \& Cham plant. Accordingly, on September $1^{\text {st }}$, in the two seasons, different plant parts of the whole plant (tip and mid cutting of 10-12 cm length, besides divisions containing foliage and root parts were planted in $10 \mathrm{~cm}$ plastic pots (one plant/pot) for every growing media used. The plants were left to grow under open field conditions. The layout of the experiment was a factorial experiment in randomized complete block design (RCBD) with three replicates (2

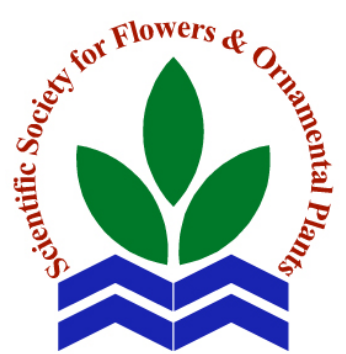

Scientific J. Flowers \& Ornamental Plants, 5(1):67-87(2018).

Received: 25/2/2018

Accepted: 8/3/2018 growing media $\times 3$ types of propagation). The results emphasized that the mixture of sand $+15 \%$ compost proved its mastery in improving vegetative growth parameters (plant height, number of branches/plant, fresh and dry weight of shoots). Besides, it was the best mixture used for raising fresh and dry weight of roots. Also, such mixture was superior in increasing survival rate \%. Meantime, it raised pigments content in the leaves (chlorophyll a, b, total chlorophylls and carotenoids). Results showed also the prevalence of using division parts in propagation, which to improvise the above mentioned morphological traits studied in both seasons. Meanwhile, using tip cuttings in propagation proved its mastery in raising survival rate \%, whereas using mid cuttings was the best in rising chlorophyll (b) in the leaves in both seasons. Also, using either mid cuttings or division parts was the best in raising total chlorophyll in the leaves. Using tip cuttings or division parts was the best in increasing carotenoids content in leaves in the first season, whereas using either mid cuttings or division plants was the best for raising the same content in the second one.

From the aforementioned results, it could be recommended to use division parts in propagation and using the mixture of sand + compost $15 \%$ in pots for obtaining the best characters of Russelia equisetiformis plant under local conditions. Moreover, a protocol of micropropagation of Russelia equisetiformis was established using nodal explants taken from the main shoot and lateral branches. Explants were sterilized using $0.1 \%(\mathrm{w} / \mathrm{v})$ mercuric chloride for 7 and $10 \mathrm{~min}$ for the main shoot and lateral branches explants, respectively as 100\% of explants were surface decontaminated, survived and stimulated to form shoots. Data of the multiplication stage showed that the highest survival 


\section{M.S. Meshaal et al.}

percentages were recorded when explants were cultured on MS medium supplemented with BAP at 0.25 or $0.50 \mathrm{mg} / \mathrm{l}$ or kin at 0.25 $\mathrm{mg} / \mathrm{l}$ which recorded 97.22, 93.06 and $94.44 \%$, respectively. The significantly highest number of the formed shootlets/explant (3.05) was obtained when medium was supplemented with $0.75 \mathrm{mg} / \mathrm{l} \mathrm{BAP}$ during the third subculture. The significantly highest value of shootlet length $(4.72 \mathrm{~cm})$ was recorded when $0.25 \mathrm{mg} / \mathrm{l}$ of kin was used during the second subculture. The most suitable treatment for rooting stage was $3 / 4$ MS strength which recorded $100 \%$ rooting, 8.86 roots/plantlet with $4.56 \mathrm{~cm}$ root length. The in vitro propagated plantlets (microshoots with well-developed roots) were hardened in greenhouse with $82 \%$ survival rate.

From the above mentioned results, it could be concluded that using tissue culture in propagation is considered the best economic way for the propagation of the Russelia equisetiformis plant comparing with that gained from the other propagation method used. Additionally, it could be mentioned that the profitability rate \% of the production by the way of tissue culture method only $780.73 \%$ comparing with $338.2 \%$ terminal cutting.

Key words: Russelia equisetiformis plant, growing media, type of propagation.

\section{INTRODUCTION}

Russelia equisetiformis Schlecht. \& Cham., common nemes: Firecrackes plant, coral plant, coral blow, fountain plant, Family Scrophulariaceae, Russelia equisetiformis is native to Mexico. It has escaped cultivation and established in disturbed sites in central and southern Florida and in other warm climate areas. Coral plant is a multi-branched sub shrub with slender, rush like stems that are angled with ridges and leaves that are reduced to little more than small scales. The wiry branches start out erect then fall over to cascade down in lengths as long as $1.2 \mathrm{~m}$ from spring until fall outdoors and all year long indoors. Coral plant produces hanging cluster of scarlet tubular flower about $2.5 \mathrm{~cm}$ long that look like little firecrackers inspiring the plant's other common name, firecrackers plant. Russelia equisetiformis is easy to propagate from cutting. It is often grown in hanging baskets. It does well on the patio or indoors in front of window. Outdoor, let the plant spill over a wall or raised bed. Stems can be tied to trellis or wall. Russelia equisetiformis plant is fast growing, early to cultivate and blooms almost continuously. This plant is a must for tropical butterfly gardens (Internet Site, 1).

Growing media have several important functions in relation to plant, as a source of water and essential plant nutrients and permit the diffusion of oxygen to the roots. Many authors agreed that sandy soil is usually considered the cheapest and most readily available material (Floyed, 1965 and Hall and Richmond, 1968). Soil fertility means the soil capacity to supply the plants with their requirements from nutrients, water and air along the growth season (Askar, 1988). Amending the organic compost and supplying it into sandy soil had highly beneficial effects on both soil properties and plant growth. Decomposition of compost allows more releasing of inorganic elements in an available form to be easily uptaken by the plant root. In addition, organic acids released during decomposition help more releasing of nutrients from the mineral portion of the soil (Shanks and Gouin, 1985) As the organic matter decompose, it becomes chemically altered, this change gives it negative charge that attracts and 
holds organic elements such as $\mathrm{K}, \mathrm{Ca}, \mathrm{Mg}$ and other micronutrients in forms that make them available for the growing plants (Wallace and Wallace, 1990). The surface charge is important in the exchange of nutrients, so although clay is full of nutrients, they tend to be bound to the particles and are not available to plant roots. The addition of lime and organic matter causes opening up of the particles so that nutrients become available (Internet Site, 2).

In this connection, many scientists on various plant species proved the great influence of using either compost or its mixture with other media in improving plant quality, Ozores-Hampton et al. (1998) reported that amending soil with mature composted waste materials has been reported to increase the growth and yields of vegetable crop, grown in Floida. Obreza and Azores (2000) stated that the main benefit of the application of compost appears to be increased nutrient availability. Significant increase in vegetative growth, flowering quality and maximum content of $\mathrm{N}, \mathrm{P}$ and $\mathrm{K}$ and the micronutrients were associated with using the organic matter in the growth medium as substrate containing biosolids. Troy and Paul (2001) worked on lobblolly pine tree growth and stated that compost was applied at rates of 5, 25 and 50 tons per acre. Planting holes were filled with either native soil or compost. The 25 ton per acre application with soil backfill increased tree survival and growth relative to control group and other compost amendments. In general, compost applications yielded soil moisture levels, higher survival rates and larger growth increases than the control group. Abdel-Sattar et al. (2010) and Gomma (2000), mentioned that sand + compost mixture induced a clear prevalence in most flowering measurements of Polianthes tuberosea besides most vegetative growth parameters. Garas (2011) recommended the use of a mixture of peatmoss + perlite $+10 \%$ compost for growing Hibiscus rosa- sinensis cv. Apple Blossom plants and supplying them with the moderate irrigation level (0.75l/pot) for producing good plant quality.
Gregory (2013) reported that seven species of flowering annuals, nine species of herbaceous perennials and eight species of woody ornamentals were grown in media containing 0, 25, 50 and 100 percent (by volume) biosolids compost, in combination with a mixture of bark, peat and sand. Results revealed that the optimal plant growth generally occurred in media containing 50 and 100 percent compost. However, plants growing in media high in compost were somewhat stunted and chlorotic for several weeks after planting.

With regard to the effect of the different methods of propagation, and concerning the cutting position along stem as well as using division parts, many workers on various plants recorded different results in this concern. Bredmose and Hansen (1996) on Rosa hybrida concluded that for internodes length, growth rate and fresh biomass efficiency the cuttings taken from the uppermost and lowermost positions generally had significantly lower values than cuttings from all medial positions. Montarone et al. (1997) reported that to understand the cuttings position effect on the rooting and the future development of Protea plants, cuttings from $P$. eximia / P. susannae cV. Sylvia and cv. Cardinal were carried out from Autumn 1994 and spring 1995. Results revealed that an important variation of rooting ability depending on stem development stage and cutting position was revealed. The best results were achieved for medial position on flower bud stems. De Andres et al. (1999) studied the effect of cuttings origin (apical, medial or basal) on vegetative propagation of Colutea arborescens and results cleared that the rooting ability of the cuttings was significantly influenced by the cutting origin. The best rooting response (95\%) was shown by basal.

Ochoa et al. (2003) worked on Nerium oleander and studied the effect of the position of the stem (apical, central and basal) from which the cutting is taken on the rooting quality of the plant from SE Spain. 


\section{M.S. Meshaal et al.}

Results showed that basal cutting produced the larger root growth, although the longer number of roots and the higher homogeneity in their distribution was obtained with apical cuttings. Teklehaimanot et al. (2004) reported that for the aim of testing the potential of stem cuttings in providing an alternative/supplement to the use of seeds an investigation into the possibility of propagating Osyris lanceolata stem cutting was carried out. Results revealed that concerning the origin of stem cuttings, basal portion had better rooting than the terminal portion.

Therefore, this paper aimed to find out the most suitable method for propagation of Russelia equisetiformis plant as well as the best growing medium for producing high plant quality under local conditions. In addition, the application of tissue culture methods for vegetative propagation of ornamental plants offers advantages over the conventional propagation methods such as disinfection, rapid multiplication of valuable genotypes, expeditious release of improved varieties, production of disease-free plants, non-seasonal production and facilitating their easy international exchange (Goviland and Gupta, 1997; Rathore et al., 2004).

Plants raised through micropropagation are produced much more rapidly, as new cultivars could become commercially available within 2 to 3 years from development rather than 5 to 10 years needed by using conventional propagation and produce uniformly superior seeds, show improved vigor and quality (Ameeta and Agrawal, 2012)

Generally, subculture effect on multiplication rate in vitro cultures varies from one species to another. A decrease in multiplication potential during long-term growth and repeated subculturing of shoots on medium of constant hormonal composition was reported in six ornamental species and cultivars of Rosaceae (Norton and Norton 1986), two cultivars of Potentilla fruticosa (Remphrey et al., 1993), various decorative plants (Varjda and Varjda, 2001), pineapple (Hamad and Taha 2008) etc. However, the point of decline is highly dependent on the treatments applied (hormonal composition of medium, incubation period etc.). Nevertheless, in dwarf raspberry (Rubus pubescens), Debnath (2004) noticed that shoot multiplication index as well as shoot length and leaves number increased with subculturing up to the third subculture period, and then remained constant.

\section{MATERIALS AND METHODS}

The experimental trial was performed throughout two successive seasons (20152016) and (2016-2017) at the nursery of Horticulture Research Institute, Agriculture Research Center, Giza, Egypt. It intended to find out the effect of the individual as well as the combined effects of different growing media and different types of propagation on morphological traits and some chemical constituents of Russelia equisetiformis plant.

\section{Materials:}

1- Russelia equisetiformis plants of three years old grown in $30 \mathrm{~cm}$ pots were used for collecting the needed parts of the plant required for propagation (tip, medial cutting and division parts).

2- Growing media:

-The mixture of sand +clay at $(1: 1, \mathrm{v} / \mathrm{v})$.

- The mixture of sand $+15 \%$ compost.

Physical and chemical properties of the growing media used are shown in Tables (a and $b)$.

\section{Procedure:}

On September $1^{\text {st }}$, in the two seasons, different plant parts were selected for using in propagation (tip and media cuttings of 10$12 \mathrm{~cm}$ length, besides division parts containing foliage and root parts. These parts were planted in every type of growing media used. Thus, 6 treatments were carried out (2 growing media $\times 3$ types of propagation). They were planted in $10 \mathrm{~cm}$ plastic pots filled with about $1 / 2 \mathrm{~kg}$ of growing media 
Table a. Physical and chemical properties of sand and clay used in plantation.

\begin{tabular}{|c|c|c|c|c|c|c|c|c|c|c|c|c|c|c|}
\hline \multirow{2}{*}{$\begin{array}{l}\text { Soil } \\
\text { texture }\end{array}$} & \multicolumn{4}{|c|}{$\begin{array}{c}\text { Particle size distribution } \\
(\%)\end{array}$} & \multirow{2}{*}{$\mathbf{p H}$} & \multirow{2}{*}{ S.P. } & \multirow{2}{*}{$\begin{array}{l}\text { E.C. } \\
(\mathrm{ds} / \mathrm{m})\end{array}$} & \multicolumn{4}{|c|}{ Cations (meq/l) } & \multicolumn{3}{|c|}{ Anions (meq/l) } \\
\hline & $\begin{array}{c}\text { Coarse } \\
\text { sand }\end{array}$ & $\begin{array}{l}\text { Fine } \\
\text { sand }\end{array}$ & Clay & Silt & & & & $\mathrm{Cu}^{++}$ & & $\mathrm{Na}^{+}$ & $\mathbf{K}^{+}$ & $\mathrm{HCO}_{3}^{-}$ & $\mathrm{Cl}^{-}$ & SO4 \\
\hline Sand & 88.04 & 3.21 & 0.72 & 8.03 & 21.1 & 7.75 & 3.46 & 13.46 & 4.98 & 20.4 & 0.62 & 2.40 & 14.5 & 22.56 \\
\hline Clay & 1.20 & 22.6 & 31.7 & 54.5 & 42.3 & 7.4 & 1.51 & 2.94 & 1.39 & 3.89 & 2.3 & 3.54 & 4.33 & 2.16 \\
\hline
\end{tabular}

Table b. Chemical properties of the used compost.

\begin{tabular}{|c|c|c|c|c|c|c|c|c|c|c|c|c|c|c|}
\hline \multirow{2}{*}{$\begin{array}{l}\text { Organic } \\
\text { additive } \\
\text { type }\end{array}$} & \multicolumn{5}{|c|}{ Macro elements (ppm) } & \multicolumn{4}{|c|}{ Micro elements (ppm) } & \multirow{2}{*}{$\begin{array}{c}\text { O.C. } \\
\%\end{array}$} & \multirow{2}{*}{$\begin{array}{c}\text { O.M. } \\
\%\end{array}$} & \multirow{2}{*}{$\begin{array}{c}\mathrm{C} / \mathrm{N} \\
\%\end{array}$} & \multirow{2}{*}{$\mathbf{p H}$} & \multirow{2}{*}{$\underset{\text { (ds/m) }}{\text { E.C. }}$} \\
\hline & $\mathbf{N}$ & $\mathbf{P}$ & $\mathbf{K}$ & Ca & Mg & Zn & $\mathbf{F e}$ & Mn & $\mathrm{Cu}$ & & & & & \\
\hline Compost & 1.41 & 0.47 & 1.82 & 0.17 & 0.74 & 28.4 & 10.2 & 110 & 40 & 12.5 & 21.5 & 8.9 & 8.1 & 4.1 \\
\hline
\end{tabular}

(one plant/pot) and the plants were left to grow under open field conditions.

A factorial experiment in randomized complete block design (RCBD) with three replicates was carried out in the two seasons. The main factor was growing media, whereas the second one was type of propagation. Every experimental unit contained 6 pots and every treatment was represented by 18 plants.

Regular agricultural practices such as weeding, fertilization, watering ... etc were carried out whenever needed, 6 months after planting i.e. the following data were recorded:

- Plant height $(\mathrm{cm})$.

- Number of branches/plant.

- Fresh and dry weight of shoots and roots (g).

- $\quad$ Survival \%.

- Chemical constituents of chlorophyll a, b and carotenoids in fresh leaves (mg/g $\mathrm{f}$. w.) was carried out according to Lichtenthaler and Wellburn (1985). Data were statistically analyzed using SAS (1995) computer program and means were compared by L.S.D. at $5 \%$ test according to Snedecor and Cochran (1990).

\section{In vitro culture trial:}

These investigations were executed during the season of 2016 -2017 on Russelia equisetiformis at Tissue Culture \& Germplasm Conservation Research Lab., Horticulture Research Institute, Agricultural Research Center, Giza, Egypt with the view to examine the effect of some factors on the behaviours of the in vitro consecutive micropropagation stages including those of explants establishment, shootlets multiplication, rooting and acclimatization stages.

Plant materials: one main stem (about 30 $\mathrm{cm}$ ) and one lateral branch (about $25 \mathrm{~cm}$ ) were taken from the nursery of the Botanical Garden Research Dept., Hort. Res. Instit., Giza.

For the culture establishment stage, the sterilized shoot tips and nodal explants were gathered and cultured into MS-medium (Murashige and Skoog, 1962) free of hormones. One month after culturing, the growing shootlets were collected, divided into nodal explants and recultured for four times into fresh MS-medium of the same composition in order to obtain a sufficient number of shootlets which might be used as resources of nodal explants for serving shootlets multiplication stage. The shootlets produced in the multiplication stage were 
applied for the rooting stage. The rooted plantlets were used for the acclimatization stage.

\section{Establishment stage:}

Prior to explant sterilization treatments, all nodal explants (about $5 \mathrm{~mm}$ long) were initially subjected to hygienic soapy (septol) water solution for $30 \mathrm{~min}$ and rinsed with running tap water for $30 \mathrm{~min}$. Under aseptic conditions in the hood cabinet, the nodal explants were immersed in ethanol (70\%) for one min. Thereafter, they were surface disinfected for $10 \mathrm{~min}$ for the main stem nodal explants and $7 \mathrm{~min}$ for lateral branch nodal explants, with $0.1 \%(\mathrm{w} / \mathrm{v})$ solution of $\mathrm{HgCl}_{2}$ (mercuric chloride) with a few drops of tween 20 as a wetting agent. After sterilization treatments, the explants were rinsed in sterilized distilled water for three times to remove all traces of disinfectant substances, and then they were inoculated vertically into autoclaved MS-medium-free hormones for four weeks. At the end of incubation period, decontamination, survival and shoot formation percentages, shoot number per explant, average shootlet length and leaves number formed per shootlet were recorded.

\section{Multiplication stage:}

In this stage, the effect of benzyl amino purine (BAP) or kinetin (kin) on in vitro behavior of shootlets multiplication was investigated (i.e., survival \%, number of shootlet per explant, length of the formed shootlet $(\mathrm{cm})$ and number of leaves per shootlet) through three successive subcultures.

In this regard, shootlet arising from the establishment were aseptically sectioned into micro cutting explants (3-5 mm long) which were used for this stage. BAPor kin were used at $0.0,0.25,0.50$ or $0.75 \mathrm{mg} / \mathrm{l}$.

One month after later, survival rate (\%) of explants, number of the formed shootlets per explant, length of the developed shootlets $(\mathrm{cm})$ and number of the initiated leaves per shootlet were recorded.

\section{Rooting stage:}

In this stage, a trial was conducted to study the influence of various MS-medium strengths, IAA and IBA on rooting behavior of the grown shootlets (i.e., rooting ability, number of initiated roots and length of the formed roots). The aseptically excised shootlet explants (35- $45 \mathrm{~mm}$ long bearing 45 leaves) produced from the multiplication stage, were vertically inoculated unto MSmedium in a different strengths of major and minor salts ( $1 / 4,1 / 2,3 / 4$ and full strength) and MS full strength plus $0.5 \mathrm{mg} / \mathrm{l}$ of IAA or IBA.

\section{Ex vitro acclimatization stage:}

The rooted plantlets $(4-5 \mathrm{~cm})$ produced from rooting stage were washed from agar and transferred into plastic pots (0.2 liter) containing peat moss saturated with $0.2 \%$ Topsin-M70 fungicide. The culture pots were covered by white transparent polyethylene bags and maintained in fiberglass-house. Two weeks later, one pore per polyethylene bag was performed, and after other two weeks the bags were gradually removed. The acclimatized plantlets were irrigated twice a week for four weeks before transplanting out-door. At the end of acclimatization stage, survival percentage was recorded. The acclimatized plants were transferred to two different potting media: sand plus $15 \%$ compost and clay plus sand $(1: 1 \mathrm{v} / \mathrm{v})$. Growth characters were recorded after six weeks.

\section{Culture medium and incubation conditions:}

MS culture medium, with or without plant growth regulators, was enriched with $3 \%$ sucrose and solidified with $0.7 \%$ Anachemia agar. The medium was adjusted to $\mathrm{pH} 5.7 \pm 0.1$ using $0.1 \mathrm{~N}$ of $\mathrm{NaOH}$ or $\mathrm{HCl}$ The prepared medium was poured at the rate of $25 \mathrm{ml}$ into $200 \mathrm{ml}$ capacity glass jars. The culture containers were covered with polypropylene lids and autoclaved at $121{ }^{\circ} \mathrm{C}$ and $1.0 \mathrm{~kg}$ for $20 \mathrm{~min}$, then left to cool and harden under sterilized laminar air flow cabinet. The cultures were incubated in 
growth chamber at $24 \pm 1^{\circ} \mathrm{C}$ temperature and $3 \mathrm{k}$ lux light intensity using $110 \mathrm{~cm}$ white florescent lamps (40 watts) for 16 hours photoperiods.

\section{Experimental design and statistical analysis of data:}

The lay-out of the experiments achieved on explants establishment and rooting stages were designed as one factor in a completely randomized design. while that of the experiment conducted for shootlets multiplication stage was arranged as two factors experiment in a completely randomized design. Data of the three series of experiments were averaged and statistically analyzed using analysis of variance. Means were compared by L.S.D. at $5 \%$ test according to Snedecor and Cochran (1990).

\section{RESULTS AND DISCUSSION}

Effect of growing media and type of propagation on vegetative growth parameters:

Data registered in Tables (1, 2, 3 and 4) revealed the prevalence of growing plants in the mixture of sand $+15 \%$ compost compared with the mixture of sand + clay $(1: 1, \quad \mathrm{v} / \mathrm{v})$ on all vegetative growth parameters studied in both seasons (plant height, number of branches/plant, fresh and dry weight of shoots) with significant differences in most cases. In this connection, Shanks and Gouin (1985) attributed the beneficial effect of using compost in improving plant growth to its great effect on both soil properties and plant growth. Additionally, decomposition of compost allows more releasing of inorganic elements in available form to be easily uptaken by the plant root. Also, organic acids released during decomposition help more releasing of nutrients from the mineral portion of the soil. However, the beneficial effect of using compost in improving plant traits was ascertained by many authors on various plants. Ozores-Hampton et al. (1998) on vegetable crops grown in Florida, Troy and Paul (2001) on loblolly pine tree growth, Abdel-Sattar et al. (2010) on Polianthes tuberosa, Garas (2011) on Hibiscus rosasinensis cv. Apple Blossom. Meanwhile, Gregory (2013) on seven species of flowering annuals, nine species of herbaceous perennials and eight species of woody ornamentals grown in media containing 0, 25, 50 and 100 percent (by volume) biosolides compost, in combination with a mixture of bark, peat and sand, found that the optimal plant growth generally occurred in media containing 50 and $100 \%$ percent compost.

Table 1. Effect of propagation types, growing media and their interaction on plant height (cm) of Russelia equisetiformis.

\begin{tabular}{lcccccc}
\hline \multirow{2}{*}{ Treatments } & \multicolumn{5}{c}{ Plant height (cm) } \\
\cline { 2 - 7 } & Clay + sand & $\begin{array}{c}\text { Season 1 } \\
\text { Sand + 15\% } \\
\text { compost }\end{array}$ & Mean (B) & Clay + sand & $\begin{array}{c}\text { Season 2 } \\
\text { Sand + 15\% } \\
\text { compost }\end{array}$ & Mean (B) \\
\hline Terminal cuttings & 31.1 & 28.8 & 29.9 & 31.3 & 26.5 & 28.9 \\
Mid cuttings & 33.3 & 29.3 & 31.3 & 35.2 & 33.7 & 34.5 \\
Division plants & 37.4 & 44.7 & 41.1 & 40.0 & 55.0 & 47.5 \\
Mean (A) & 33.9 & 34.3 & & 35.5 & 38.4 & \\
L.S.D. & $\mathrm{A}=\mathrm{N} . \mathrm{S}$. & $\mathrm{B}=5.06$ & $\mathrm{~A} \times \mathrm{B}=7.15$ & $\mathrm{~A}=$ N.S. & $\mathrm{B}=4.69$ & $\mathrm{~A} \times \mathrm{B}=6.64$ \\
\hline
\end{tabular}


Table 2. Effect of propagation types, growing media and their interaction on number of branches/plant of Russelia equisetiformis.

\begin{tabular}{lcccccc}
\hline \multirow{2}{*}{ Treatments } & \multicolumn{5}{c}{ Number of branches/plant } \\
\cline { 2 - 7 } & Clay + sand & $\begin{array}{c}\text { Season 1 } \\
\text { Sand + 15\% } \\
\text { compost }\end{array}$ & Mean (B) & Clay + sand & $\begin{array}{c}\text { Season 2 } \\
\text { Sand + 15\% } \\
\text { compost }\end{array}$ & Mean (B) \\
\hline Terminal cuttings & 130 & 148.5 & 139.3 & 135.7 & 151.5 & 143.6 \\
Mid cuttings & 133.9 & 154.7 & 144.3 & 145.2 & 161.1 & 153.2 \\
Division plants & 244.3 & 262.1 & 253.2 & 257.0 & 273.5 & 265.3 \\
Mean (A) & 169.4 & 188.5 & & 179.3 & 195.4 & \\
L.S.D. & $\mathrm{A}=5.56$ & $\mathrm{~B}=6.81$ & $\mathrm{~A} \times \mathrm{B}=9.63$ & $\mathrm{~A}=5.01$ & $\mathrm{~B}=6.14$ & $\mathrm{~A} \times \mathrm{B}=8.68$ \\
\hline
\end{tabular}

Table 3. Effect of propagation types, growing media and their interaction on fresh weight of shoots (g) of Russelia equisetiformis.

\begin{tabular}{lcccccc}
\hline \multirow{1}{*}{ Treatments } & \multicolumn{5}{c}{ Fresh weight of shoots (g) } \\
\cline { 2 - 7 } & Clay + sand & $\begin{array}{c}\text { Season 1 } \\
\text { Sand + 15\% } \\
\text { compost }\end{array}$ & Mean (B) & Clay + sand & $\begin{array}{c}\text { Season 2 } \\
\text { Sand + 15\% } \\
\text { compost }\end{array}$ & Mean (B) \\
\hline Terminal cuttings & 2.7 & 3.3 & 3.0 & 3.0 & 3.6 & 3.3 \\
Mid cuttings & 2.9 & 3.7 & 3.3 & 3.1 & 3.8 & 3.5 \\
Division plants & 6.3 & 7.5 & 6.9 & 6.8 & 8.9 & 7.8 \\
Mean (A) & 3.96 & 4.83 & & 4.3 & 5.4 & \\
L.S.D. & A=N.S. & B=0.35 & A $\times \mathrm{B}=0.49$ & A= N.S. B=0.36 & $A \times B=0.50$ \\
\hline
\end{tabular}

Table 4. Effect of propagation types, growing media and their interaction on dry weight of shoots (g) of Russelia equisetiformis.

\begin{tabular}{|c|c|c|c|c|c|c|}
\hline \multirow{3}{*}{ Treatments } & \multicolumn{6}{|c|}{ Dry weight of shoot (g) } \\
\hline & \multicolumn{3}{|c|}{ Season 1} & \multicolumn{3}{|c|}{ Season 2} \\
\hline & Clay + sand & $\begin{array}{c}\text { Sand }+15 \% \\
\text { compost }\end{array}$ & Mean (B) & Clay + sand & $\begin{array}{c}\text { Sand }+15 \% \\
\text { compost }\end{array}$ & Mean (B) \\
\hline Terminal cuttings & 1.04 & 1.05 & 1.05 & 1.12 & 1.27 & 1.20 \\
\hline Mid cuttings & 1.07 & 1.15 & 1.11 & 1.17 & 1.24 & 1.21 \\
\hline Division plants & 2.44 & 2.52 & 2.48 & 2.87 & 3.9 & 3.39 \\
\hline Mean (A) & 1.52 & 1.57 & & 1.72 & 2.14 & \\
\hline L.S.D. & $A=N . S$. & $B=0.12$ & $\mathrm{~A} \times \mathrm{B}=0.17$ & $A=0.20$ & $B=0.25 \quad A$ & $\mathrm{~A} \times \mathrm{B}=0.35$ \\
\hline
\end{tabular}

Type of propagation, on the other side, indicated the superiority of using division parts in propagation for improving all the above mentioned traits in the two seasons. In relation to the interaction, data presented in Tables (1, 2, 3 and 4) reveal the mastery of using division parts in propagation and using the mixture of sand $+15 \%$ compost, followed by plants propagated by mid cuttings and using the mixture of sand+ clay in the two seasons. In contrast, the least results were recorded due to using terminal cuttings in propagation and planting in the mixture of sand + clay $(1: 1, \mathrm{v} / \mathrm{v})$. In this connection, Bredmose and Hansen (1996) confirmed such result on Rosa hybrid L. They claimed that cuttings taken from uppermost and the lower most positions generally had significantly lower values than cuttings for all medial positions. 
Effect of growing media and type of propagation on fresh and dry weights of roots:

The different media used indicated that the mixture of sand $+15 \%$ compost was the best medium used in raising fresh and dry weight of roots compared with that obtained from the mixture of sand + clay $(1: 1, \mathrm{v} / \mathrm{v})$ medium in the two seasons. The prevalence of compost in improving root quality was also recorded by many authors such as AlAshry et al. (1998) on Dracaena reflexa, Ibrahim et al. (1998) on Monstera deliciosa and Singh and Nair (2003) on some foliage plants.

On the other hand, using division parts in propagation proved its superiority in increasing fresh and dry weights of roots compared with that gained from the other propagation methods as indicated in Tables (5 and 6). Concerning the interaction, it is evident from scored values the clear increment in fresh and dry weights of roots due to using division parts in propagation and planting in the mixture of sand $+15 \%$ compost medium followed by using the same way of propagation and planting in the mixture of sand + clay medium with significant differences in the two seasons. In contrast, the least scores were gained due to using terminal cuttings in propagation and planting in the mixture of sand + clay $(1: 1$, $\mathrm{v} / \mathrm{v}$ ) in both seasons. However, theleast beneficial effect of using terminal cutting in propagation is in conformity with the findings of other authors.

Table 5. Effect of propagation types, growing media and their interaction on fresh weight of roots (g) of Russelia equisetiformis.

\begin{tabular}{lcccccc}
\hline \multicolumn{1}{c}{ Treatments } & \multicolumn{5}{c}{ Fresh weight of roots (g) } \\
\cline { 2 - 7 } & Clay + sand & $\begin{array}{c}\text { Season 1 } \\
\text { Sand + 15\% } \\
\text { compost }\end{array}$ & Mean (B) & Clay + sand & $\begin{array}{c}\text { Season 2 } \\
\text { Sand + 15\% } \\
\text { compost }\end{array}$ & Mean (B) \\
\hline Terminal cuttings & 0.41 & 0.60 & 0.51 & 0.55 & 0.85 & 0.70 \\
Mid cuttings & 0.45 & 0.90 & 0.68 & 0.69 & 1.20 & 0.95 \\
Division plants & 2.26 & 2.70 & 2.48 & 2.55 & 2.80 & 2.68 \\
Mean (A) & 1.04 & 1.4 & 1.26 & 1.61 & $\mathrm{~A}=0.30$ \\
L.S.D. & $\mathrm{A}=0.27=0.38$ & $\mathrm{~B}=0.34 \mathrm{~A} \times \mathrm{B}=0.56$ \\
\hline
\end{tabular}

Table 6. Effect of propagation types, growing media and their interaction on dry weight of roots (g) of Russelia equisetiformis.

\begin{tabular}{|c|c|c|c|c|c|c|}
\hline \multirow{3}{*}{ Treatments } & \multicolumn{6}{|c|}{ Dry weight of roots (g) } \\
\hline & \multicolumn{3}{|c|}{ Season 1} & \multicolumn{3}{|c|}{ Season 2} \\
\hline & Clay + sand & $\begin{array}{c}\text { Sand }+15 \% \\
\text { compost }\end{array}$ & Mean (B) & Clay + sand & $\begin{array}{c}\text { Sand }+15 \% \\
\text { compost }\end{array}$ & Mean (B) \\
\hline Terminal cuttings & 0.15 & 0.22 & 0.19 & 0.19 & 0.23 & 0.21 \\
\hline Mid cuttings & 0.20 & 0.24 & 0.22 & 0.22 & 0.30 & 0.26 \\
\hline Division plants & 1.28 & 1.4 & 1.34 & 1.33 & 1.7 & 1.52 \\
\hline Mean (A) & 0.54 & 0.62 & & 0.58 & 0.74 & \\
\hline L.S.D. & $A=0.06$ & $B=0.08 \quad A$ & $\mathrm{~A} \times \mathrm{B}=0.11$ & $A=0.12$ & $B=0.15$ & $A \times B=0.22$ \\
\hline
\end{tabular}


Bredmose and Hansen (1996) on Rosa hybrid concluded that for internodes length, growth rate and fresh biomass efficiency the cuttings taken from the uppermost and lowermost positions, generally had significantly lower values than cuttings for all medial position. Montarone et al. (1997) on genus Protea stated that an important variation of rooting ability depends on stem development state and cutting position. The best results were achieved for medial position of flower bud stem.

\section{Effect of growing media and type of propagation on survival rate $\%$ :}

With respect to survival \% it is obvious from data outlined in Table (7) that the mixture of sand $+15 \%$ compost raised survival \% more than that gained by the mixture of sand + clay $(1: 1, \mathrm{v} / \mathrm{v})$ in both seasons. Meanwhile, using tip cuttings in propagation proved its mastery in raising survival \% more those that obtained from other methods used in propagation in the two seasons. Concerning the interaction, it is clear from data presented in Table (7), the mastery of using division parts in propagation and planting in the mixture of sand $+15 \%$ compost in raising survival rate $\%$ in both seasons. Meanwhile, the least scores were registered as a result of using mid cutting in propagation with planting in the mixture of sand $+15 \%$ compost in both seasons. In this connection the beneficial effect of using compost in raising survival rate was also recorded by Troy and Paul (2001) on lobblolly pine tree. They reported that compost application yielded higher soil moisture levels, higher survival rates and higher growth increase than the control group.

Effect of growing media and type of propagation on pigments content in the leaves:

In both seasons, using the mixture of sand $+15 \%$ compost in potting raised pigments content in the leaves (chlorophyll a, b, total chlorophyll and carotenoids) more than that gained from the mixture of sand+ clay $(1: 1, \mathrm{v} / \mathrm{v})$ as indicated in Tables $(8,9,10$ and 11).

Table 7. Effect of propagation types, growing media and their interaction on survival rate \% of Russelia equisetiformis.

\begin{tabular}{lcccccc}
\hline \multirow{2}{*}{ Treatments } & \multicolumn{5}{c}{ Survival (\%) } \\
\cline { 2 - 7 } & Clay + sand & $\begin{array}{c}\text { Season 1 } \\
\text { Sand + 15\% } \\
\text { compost }\end{array}$ & Mean (B) & Clay + sand & $\begin{array}{c}\text { Season 2 } \\
\text { Sand + 15\% } \\
\text { compost }\end{array}$ & Mean (B) \\
\hline Terminal cuttings & 79.7 & 84.7 & 82.2 & 81.3 & 85.4 & 83.4 \\
Mid cuttings & 77.1 & 74.7 & 75.9 & 80.5 & 76.5 & 78.5 \\
Division plants & 88.5 & 91.1 & 89.8 & 89.7 & 94 & 91.85 \\
Mean (A) & 81.8 & 83.5 & & 83.8 & 85.3 & \\
\hline
\end{tabular}

Table 8. Effect of propagation types, growing media and their interaction on chlorophyll a (mg/g f.w.) of Russelia equisetiformis leaves.

\begin{tabular}{lcccccc}
\hline \multirow{2}{*}{ Treatments } & \multicolumn{5}{c}{ Chlorophyll a (mg/g f.w.) } \\
\cline { 2 - 7 } & Clay + sand & $\begin{array}{c}\text { Season 1 } \\
\text { Sand + 15\% } \\
\text { compost }\end{array}$ & Mean (B) & Clay + sand & $\begin{array}{c}\text { Season 2 } \\
\text { Sand + 15\% } \\
\text { compost }\end{array}$ & Mean (B) \\
\hline Terminal cuttings & 0.53 & 0.59 & 0.56 & 0.58 & 0.60 & 0.59 \\
Mid cuttings & 0.54 & 0.62 & 0.58 & 0.56 & 0.64 & 0.60 \\
Division plants & 0.59 & 0.65 & 0.62 & 0.58 & 0.71 & 0.65 \\
Mean (A) & 0.55 & 0.62 & & 0.57 & 0.65 & \\
L.S.D. & $\mathrm{A}=0.04$ & $\mathrm{~B}=0.05$ & $\mathrm{~A} \times \mathrm{B}=0.08$ & $\mathrm{~A}=0.04$ & $\mathrm{~B}=0.04$ & $\mathrm{~A} \times \mathrm{B}=0.07$ \\
\hline
\end{tabular}


Table 9. Effect of propagation types, growing media and their interaction on chlorophyll b (mg/g f.w.) of Russelia equisetiformis.

\begin{tabular}{|c|c|c|c|c|c|c|}
\hline \multirow{3}{*}{ Treatments } & \multicolumn{6}{|c|}{ Chlorophyll b (mg/g f.w.) } \\
\hline & \multicolumn{3}{|c|}{ Season 1} & \multicolumn{3}{|c|}{ Season 2} \\
\hline & Clay + sand & $\begin{array}{c}\text { Sand }+15 \% \\
\text { compost }\end{array}$ & Mean (B) & Clay + sand & $\begin{array}{c}\text { Sand }+15 \% \\
\text { compost }\end{array}$ & Mean (B) \\
\hline Terminal cuttings & 0.18 & 0.23 & 0.20 & 0.19 & 0.25 & 0.22 \\
\hline Mid cuttings & 0.20 & 0.25 & 0.23 & 0.22 & 0.33 & 0.28 \\
\hline Division plants & 0.23 & 0.22 & 0.23 & 0.27 & 0.16 & 0.22 \\
\hline Mean (A) & 0.20 & 0.23 & & 0.23 & 0.25 & \\
\hline L.S.D. & $A=0.01$ & $B=0.02 \quad A \times I$ & $=0.04$ & $A=0.01$ & $\mathrm{~B}=0.01$ & $=0.02$ \\
\hline
\end{tabular}

Table 10. Effect of propagation types, growing media and their interaction on total chlorophyll (mg/g f.w.) of Russelia equisetiformis leaves.

\begin{tabular}{|c|c|c|c|c|c|c|}
\hline \multirow{3}{*}{ Treatments } & \multicolumn{6}{|c|}{ Total chlorophylls (mg/g f.w.) } \\
\hline & \multicolumn{3}{|c|}{ Season 1} & \multicolumn{3}{|c|}{ Season 2} \\
\hline & Clay + sand & $\begin{array}{c}\text { Sand }+15 \% \\
\text { compost }\end{array}$ & Mean (B) & Clay + sand & $\begin{array}{c}\text { Sand }+15 \% \\
\text { compost }\end{array}$ & Mean (B) \\
\hline Terminal cuttings & 0.71 & 0.82 & 0.77 & 0.77 & 0.85 & 0.81 \\
\hline Mid cuttings & 0.74 & 0.87 & 0.87 & 0.78 & 0.96 & 0.89 \\
\hline Division plants & 0.82 & 0.88 & 0.85 & 0.85 & 0.87 & 0.86 \\
\hline Mean (A) & 0.76 & 0.86 & & 0.77 & 0.87 & \\
\hline L.S.D. & $A=0.01$ & $\mathrm{~B}=0.02$ & $\mathrm{~A} \times \mathrm{B}=0.023$ & $A=0.05$ & $B=0.07$ & $A \times B=0.09$ \\
\hline
\end{tabular}

Table 11. Effect of propagation types, growing media and their interaction on carotenoids content (mg/g f.w.) of Russelia equisetiformis leaves.

\begin{tabular}{|c|c|c|c|c|c|c|}
\hline \multirow{3}{*}{ Treatments } & \multicolumn{6}{|c|}{ Carotenoids ( mg/g f.w.) } \\
\hline & \multicolumn{3}{|c|}{ Season 1} & \multicolumn{3}{|c|}{ Season 2} \\
\hline & Clay + sand & $\begin{array}{c}\text { Sand }+15 \% \\
\text { compost }\end{array}$ & Mean (B) & Clay + sand & $\begin{array}{c}\text { Sand }+15 \% \\
\text { compost }\end{array}$ & Mean (B) \\
\hline Terminal cuttings & 0.17 & 0.19 & 0.18 & 0.11 & 0.19 & 0.15 \\
\hline Mid cuttings & 0.12 & 0.16 & 0.14 & 0.17 & 0.14 & 0.16 \\
\hline Division plants & 0.15 & 0.20 & 0.18 & 0.16 & 0.18 & 0.17 \\
\hline Mean (A) & 0.15 & 0.18 & & 0.15 & 0.17 & \\
\hline L.S.D. & $A=0.01$ & $B=0.02$ & $3=$ N.S. & $A=0.0$ & $B=0.01 \quad A$ & $B=N . S$. \\
\hline
\end{tabular}

Meanwhile, the different methods of propagation differed in their effects on pigments content in the leaves, where using division parts in propagation was the best in raising chlorophyll content in both seasons. Using mid cuttings was the best in raising chlorophyll (b) in the leaves in both seasons. Also, using either mid cutting or division parts in propagation was the best for raising total chlorophyll in the leaves in the two seasons. Meantime using tip cutting or division plants in propagation was the best for increasing carotenoids content in the first season, whereas applying either mid cutting or division plants in propagation was the best treatments in raising the same content in the second one. Referring to the two interactions, the best treatments were that of using either terminal cuttings or division parts in propagation and using the mixture of sand $+15 \%$ compost medium in potting in the two seasons. 


\section{M.S. Meshaal et al.}

\section{Establishment stage:}

Data presented in Table (12) represent the effect of explants type of $R$. equisetiformis on its response to grow in vitro during the establishment stage. It is cleared that there were no significant differences between the two explant types used (main stem and lateral branch) in the different parameters i.e., decontamination percentage, survival and shoot formation percentages, number and length of the grown shootlets and number of leaves formed per shootlet.

Since there is significant difference between the means, lateral branches can be considered as a source of explants for establishment stage to save the main stem. The goal of establishment stage is the initiation of aseptic and responsive terminal or lateral buds. Many factors affect the success of this stage such as explantation time, position of explant on the stem, size of explant and polyphenol oxidation. Explants exhibited different capacities for their establishment in vitro depending on the location of the bud on the donor plant (Trigiano and Gra, 2000).

\section{Multiplication stage:}

\section{Survival percentage:}

Data presented in Table (13) show the effect of different growth regulators on survival percentages through three successive subcultures. Concerning the effect of subculture, it is noticed that survival percentage significantly increased from the first to the second subculture (from 80.56 to $92.36 \%)$ and from the second to the third subculture (from 92.36 to 93.75\%). Data showed also that plant growth regulators had a significant influence on shootlets survival percentage. The highest survival percentage was recorded when shootlets were subcultured on MS medium supplemented with BAP at 0.25 or $0.50 \mathrm{mg} / \mathrm{l}$ or with kin at $0.25 \mathrm{mg} / \mathrm{l}$ (97.22, 93.06 and 94.44\%, respectively). The significantly lowest survival (77.78\%) was obtained when culture medium was supplemented with kin at 0.75 $\mathrm{mg} / \mathrm{l}$. The interaction between number of subcultures and plant growth regulators also had a significant effect on shootlets survival percentage. Generally, survival percentage increased with repetitive subcultures. Survival percentage reached its maximum (100\%) when explants were subcultured on MS medium augmented with 0.25 or 0.75 $\mathrm{mg} / \mathrm{l}$ BAP during the second subculture and when medium was supplemented with 0.50 , $0.75 \mathrm{mg} / \mathrm{l}$ BAP or with $0.25 \mathrm{mg} / \mathrm{l}$ kin during the third subculture. On the other hand, the significantly lowest survival percentage (66.67\%) was recorded when BAP was applied at $0.75 \mathrm{mg} / \mathrm{l}$ on the first subculture.

\section{Shootlet number/explant:}

The effect of the repetitive subcultures and cytokinin types and concentrations on number of shootlets formed per explant is shown in Table (14). Data declared that number of shootlets formed per explant was significantly affected by subculture number. The number of the formed shootlets insignificantly increased from the first to the second subculture, while it was significantly increased from the second to the third subculture (from 1.97 to 2.335 ).

Table 12. In vitro culture response of $R$. equisetiformis during establishment stage as affected by explants type.

\begin{tabular}{lcccccc}
\hline $\begin{array}{l}\text { Source of plants } \\
\text { type }\end{array}$ & $\begin{array}{c}\text { Decont. } \\
\mathbf{\%}\end{array}$ & $\begin{array}{c}\text { Survival } \\
\mathbf{\%}\end{array}$ & $\begin{array}{c}\text { Shooting } \\
\mathbf{\%}\end{array}$ & Shoot No. & $\begin{array}{c}\text { Shoot length } \\
\text { (cm) }\end{array}$ & Leaves No. \\
\hline Main shoot & 100 & 100 & 100 & 2.83 & 2.31 & 6.24 \\
Lateral branch & 100 & 100 & 100 & 1.85 & 2.54 & 6.95 \\
L.S.D (5\%) & N.S & N.S & N.S & N.S & N.S & N.S \\
\hline
\end{tabular}


Table 13. Effect of different growth regulators (types and concentration) through three successive subcultures on shootlets survival percentage of $R$. equisetiformis during multiplication stage.

\begin{tabular}{|c|c|c|c|c|}
\hline $\begin{array}{l}\text { Subculture (B) } \\
\text { Growth regulators (mg/l) (A) }\end{array}$ & $1^{\text {st }}$ & $2^{\text {nd }}$ & $3^{\text {rd }}$ & $\begin{array}{l}\text { Mean of growth } \\
\text { regulators (A) }\end{array}$ \\
\hline 0.0 & 36.50 & 35.20 & 32.50 & 34.73 \\
\hline $0.25 \mathrm{mg} / \mathrm{l} \mathrm{BAP}$ & 95.83 & 100.00 & 95.83 & 97.22 \\
\hline $0.50 \mathrm{mg} / \mathrm{l}$ BAP & 83.33 & 95.83 & 100.00 & 93.06 \\
\hline $0.75 \mathrm{mg} / \mathrm{l} \mathrm{BAP}$ & 66.67 & 100.00 & 100.00 & 88.89 \\
\hline $0.25 \mathrm{mg} / \mathrm{l} \mathrm{kin}$ & 87.50 & 95.83 & 100.00 & 94.44 \\
\hline $0.50 \mathrm{mg} / \mathrm{l} \mathrm{kin}$ & 70.83 & 83.33 & 91.67 & 81.94 \\
\hline $0.75 \mathrm{mg} / \mathrm{l}$ kin & 79.17 & 79.17 & 75.00 & 77.78 \\
\hline Mean of subcultures (B) & 74.21 & 84.19 & 85.00 & \\
\hline L.S.D (5\%) & & $A=6.607$ & $B=9.344$ & $A \times B=16.18$ \\
\hline
\end{tabular}

Table 14. Effect of different growth regulators (types and concentrations) through three successive subcultures on shootlet No./explant of $R$. equisetiformis during multiplication stage.

\begin{tabular}{|c|c|c|c|c|}
\hline $\begin{array}{l}\text { Subculture (B) } \\
\text { Growth regulators }(\mathrm{mg} / \mathrm{l})(\mathrm{A})\end{array}$ & $1^{\text {st }}$ & $2^{\text {nd }}$ & $3^{\text {rd }}$ & $\begin{array}{l}\text { Mean of growth } \\
\text { regulators (A) }\end{array}$ \\
\hline 0.0 & 1.00 & 1.00 & 1.00 & 1.00 \\
\hline $0.25 \mathrm{mg} / \mathrm{l} \mathrm{BAP}$ & 1.93 & 1.75 & 2.14 & 1.94 \\
\hline $0.50 \mathrm{mg} / \mathrm{l} \mathrm{BAP}$ & 1.50 & 2.27 & 2.94 & 2.24 \\
\hline $0.75 \mathrm{mg} / \mathrm{l} \mathrm{BAP}$ & 2.48 & 2.13 & 3.05 & 2.55 \\
\hline $0.25 \mathrm{mg} / \mathrm{l} \mathrm{kin}$ & 1.60 & 1.38 & 2.1 & 1.69 \\
\hline $0.50 \mathrm{mg} / \mathrm{l} \mathrm{kin}$ & 1.28 & 1.51 & 2.22 & 1.66 \\
\hline $0.75 \mathrm{mg} / \mathrm{l} \mathrm{kin}$ & 1.58 & 1.72 & 1.56 & 1.62 \\
\hline Mean of subcultures (B) & 1.628 & 1.68 & 2.14 & \\
\hline L.S.D (5\%) & & & $B=0.3951$ & $\mathrm{~A} \times \mathrm{B}=0.6844$ \\
\hline
\end{tabular}

Data showed also that cytokinens had a significant effect on shootlets number. The maximum number of the formed shootlets (2.55/explant) was obtained when medium was supplemented with $0.75 \mathrm{mg} / \mathrm{L}$ BAP. The formed shootlets were significantly increased with increasing BAP concentration (from 1.94 to 2.55) while they insignificantly decreased with increasing kinetin concentration (from 1.69 to 1.62). The interaction between subculture and cytokinin was studied. The highest significant number of shootlets (3.05) was formed on explants cultured on medium supplemented with 0.75
mg/L BAP during the third subculture. However, the lowest number (1.28) was achieved when $0.5 \mathrm{mg} / \mathrm{l}$ kin was used during the first subculture. During the third subculture, with increasing BAP concentration from 0.25 to $0.75 \mathrm{mg} / \mathrm{l}$, the number of shootlets was increased by $29.8 \%$, while it was decreased by $25.7 \%$ when BAP was replaced by kin at the same concentrations. In order to obtain high multiplication rates, relatively large amounts of cytokinins are used in multiplication media. However, in some other plants the multiplication rate decreases with increasing 
the concentration of cytokinins in the medium (Corchete et al., 1997). Shekhawat and Manokari (2015) established a protocol for micropropagation of Russelia equisetiformis through nodal shoot segments cultured on MS supplemented with different concentrations and combinations of cytokinins and auxins. They found that the highest percent of bud breaking response with maximum number of shoots was observed on MS medium augmented with $1.0 \mathrm{mg} / \mathrm{l}$ BAP. They reported also that shootlets multiplication further enhanced by repeated in vitro subculturing. In the micropropagation of numerous plants, BAP is much more effective than kinetin (Evaldsson \&Welander, 1985; Wong, 1986). According to Islam et al. (2005) 4.44-6.66 $\mu \mathrm{M}$ BA was found to be the best for shooting response. On the other hand, when the stem explants from in vitro drumstick tree plantlets were cultured on MS agar medium supplemented with 6 different concentrations of BAP for 5 weeks, it was found that all the media (except for BAP at $0.5 \mathrm{mg} / \mathrm{l}$ ) induced $100 \%$ shoot formation (Riyathong et al., 2010).

\section{Shootlet length:}

As shown in Table (15), data emphasized that the length of the formed shootlets was significantly influenced by subculture number, supplemented cytokinins and their interaction. Generally, the mean shootlet length insignificantly increased with increasing subculture number from the first to the second (from 2.95 to 3.29) and significantly from the second to the third (from 3.29 to 3.64). The significantly highest shootlet length $(4.16 \mathrm{~cm})$ was recorded with

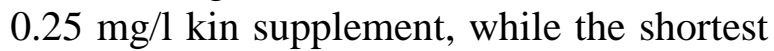
one (2.31) was recorded with $0.75 \mathrm{mg} / \mathrm{l}$ BAP. Considering the interaction effect, the significantly highest value of shootlet length $(4.72 \mathrm{~cm})$ was recorded when $0.25 \mathrm{mg} / \mathrm{l}$ of kin was used during the second subculture. However, the significantly shortest shootlets $(2.13 \mathrm{~cm})$ was measured during the first subculture on medium augmented with 0.75 mg/l BAP. During the three subcultures, the shootlets length was reversely related with BAP concentration and kin as well.

\section{Leaves number/shootlet:}

Data presented in Table (16) represent the effect of cytokinin type and concentration on leaves number per shootlet through three successive subcultures. The values were significantly increased from the first to the second subculture (from 6.88 to 7.68) and stayed at the same level in the third subculture (7.67).

Table 15. Effect of different growth regulators (types and concentrations) through three successive subcultures on shootlet length $(\mathrm{cm})$ of $R$. equisetiformis during multiplication stage.

\begin{tabular}{lcccc}
\hline \multicolumn{1}{c}{ Subculture (B) } & $\mathbf{1}^{\text {st }}$ & $\mathbf{2}^{\text {nd }}$ & $\mathbf{3}^{\text {rd }}$ & $\begin{array}{c}\text { Mean of growth } \\
\text { regulators (A) }\end{array}$ \\
\hline $\mathbf{0 . 0}$ & 1.68 & 1.51 & 1.04 & 1.41 \\
$\mathbf{0 . 2 5} \mathbf{~ m g / l ~ B A P ~}$ & 3.61 & 2.65 & 4.03 & 3.43 \\
$\mathbf{0 . 5 0} \mathbf{~ m g / l ~ B A P ~}$ & 2.43 & 2.37 & 3.42 & 2.74 \\
$\mathbf{0 . 7 5} \mathbf{~ m g / l ~ B A P ~}$ & 2.13 & 2.35 & 2.43 & 2.31 \\
$\mathbf{0 . 2 5} \mathbf{~ m g / l ~ k i n ~}$ & 3.32 & 4.72 & 4.43 & 4.16 \\
$\mathbf{0 . 5 0} \mathbf{~ m g / l ~ k i n ~}$ & 3.38 & 3.28 & 4.02 & 3.56 \\
$\mathbf{0 . 7 5} \mathbf{~ m g / l ~ k i n ~}$ & 2.83 & 4.37 & 3.52 & 3.57 \\
Mean of subcultures (B) & 2.70 & 3.03 & 3.27 & \\
L.S.D (5\%) & \multicolumn{2}{c}{$\mathrm{A}=0.3787$} & $\mathrm{~B}=0.5355$ & $\mathrm{~A} \times \mathrm{B}=0.9276$ \\
\hline
\end{tabular}


Table 16. Effect of different growth regulators (types and concentrations) through three successive subcultures on leaves No./shootlet of $R$. equisetiformis during multiplication stage.

\begin{tabular}{lcccc}
\hline \multicolumn{1}{c}{ Subculture (B) } & $\mathbf{1}^{\text {st }}$ & $\mathbf{2}^{\text {nd }}$ & $\mathbf{3}^{\text {rd }}$ & $\begin{array}{c}\text { Mean of growth } \\
\text { regulators (A) }\end{array}$ \\
\hline $\mathbf{0 . 0}$ & 3.54 & 3.27 & 3.16 & 3.32 \\
$\mathbf{0 . 2 5} \mathbf{~ m g / l ~ B A P ~}$ & 7.51 & 6.42 & 7.37 & 7.10 \\
$\mathbf{0 . 5 0} \mathbf{~ m g / l ~ B A P ~}$ & 7.05 & 7.7 & 8.27 & 7.68 \\
$\mathbf{0 . 7 5} \mathbf{~ m g / l ~ B A P ~}$ & 6.32 & 8.20 & 8.00 & 7.51 \\
$\mathbf{0 . 2 5} \mathbf{~ m g / l ~ k i n ~}$ & 6.83 & 8.32 & 8.23 & 7.79 \\
$\mathbf{0 . 5 0} \mathbf{~ m g / l ~ k i n ~}$ & 6.82 & 7.53 & 7.09 & 7.15 \\
$\mathbf{0 . 7 5} \mathbf{~ m g / l ~ k i n ~}$ & 6.75 & 7.88 & 7.05 & 7.23 \\
Mean of subcultures (B) & 6.40 & 7.05 & 7.03 & \\
L.S.D (5\%) & \multicolumn{2}{c}{$\mathrm{A}=0.6033$} & $\mathrm{~B}=\mathrm{N} . \mathrm{S}$ & $\mathrm{A} \times \mathrm{B}=1.478$ \\
\hline
\end{tabular}

The mean effect of cytokinin type and concentration was not significant. The interaction effect indicated that the significantly greatest number of leaves (8.32) was induced by medium supplemented with $0.25 \mathrm{mg} / \mathrm{l} \mathrm{kin} \mathrm{during} \mathrm{the} \mathrm{second} \mathrm{subculture,}$ while the lowest significantly lowest one (6.32) was recorded for medium supplemented with $0.75 \mathrm{mg} / \mathrm{l}$ BAP during the first subculture.

\section{Rooting stage:}

Rooting stage behavior as affected by MS strength and auxins is shown in Table (17). Rooting percentage, root number per plantlet and root length were significantly influenced by the different factors under investigation. Rooting percentage reached $100 \%$ when $3 / 4$ and full MS and $0.5 \mathrm{mg} / \mathrm{l}$ of IAA or IBA were used. Using $1 / 2$ MS led to the significantly lowest rooting (88.04\%). The significantly highest root number (9.46) was recorded when $1 / 4 \mathrm{MS}$ was used. while, it decreased to 6.48 when full strength was used. Root length recorded its maximum value $(6.72 \mathrm{~cm})$ with $\mathrm{MS}$ at $1 / 4$ strength, whereas the significantly shortest one (3.02 $\mathrm{cm})$ was recorded when IAA was used. Generally, the most suitable treatment for rooting stage is $3 / 4$ MS strength which recorded $100 \%$ rooting, 8.86 roots/plantlet with $4.56 \mathrm{~cm}$ root length. Concerning the effect of medium strength, Polisetty et al. (1996) found that maximum rooting of Cicer arietnum was observed when cultured in quarter strength of MS medium.

On the other hand, Sayed et al. (2005) pointed out that all MS medium strengths tested (full, half and quarter) induced Cereus peruvianus to form roots. The effect of medium strength on number of roots formed per microshoot was previously studied by Abou Dahab et al. (2005) on Ruscus hypoglossum and they found that number of roots per microshoot was increased from 0.33 to 0.66 and 1.33 with decreasing medium strength from full to half and quarter strength, respectively.

As mentioned by Shekhawat and Manokari (2015), healthy microshoots of Russelia equisetiformis were rooted with high frequency (97\%) on half strength MS medium containing $1.0 \mathrm{mg} / \mathrm{l}$ IBA with maximum number of roots (5.73). Sakr et al. (1999) noted that when shoots of Yucca elephantipes were transferred to MS rooting medium, longer roots were developed on full strength than on half strength MS medium and these results are in agreement with our results.

\section{Acclimatization stage:}

Well rooted plantlets were acclimatized successfully in green house using peat moss 
M.S. Meshaal et al.

Table 17. Effect of MS strength and auxin type on in vitro rooting stage of $R$. equisetiformis.

\begin{tabular}{lccc}
\hline Treatments & Rooting (\%) & Root No. & Root length (cm) \\
\hline 1/4 strength of MS & 96.60 & 9.46 & 6.72 \\
1/2 strength of MS & 88.04 & 6.70 & 4.36 \\
3/4 strength of MS & 100 & 8.86 & 4.56 \\
Full strength of MS & 100 & 6.48 & 5.38 \\
MS + 0.5 mg/l IBA & 100 & 8.52 & 4.18 \\
MS + 0.5 mg/l IAA & 100 & 6.62 & 3.02 \\
L.S.D. (5\%) & 7.98 & 1.71 & 1.25 \\
\hline
\end{tabular}

at rate of $82 \%$. Data in Table (18) represent the growth characters of the acclimatized plants using two different potting media; sand $+15 \%$ compost and clay + sand $(1: 1 \mathrm{v} / \mathrm{v})$. It is clear that there were are non significant differences in all growth characters under investigation except for survival \% which was significantly higher when sand and compost was used (89.86\%). The plant height ranged from 27.86 to 28.79 cm.

\section{Economic feasibility:}

Data registered in Tables (19 and 20) revealed that the highest profitability was achieved in the type of propagation of the terminal cutting grown in the medium of sand + compost 15\% recorded 338.2\% compared with other propagation types. Whereas, in tissue culture gave the highest value $(780.73 \%)$ in sand + compost $15 \%$ medium.

It is clear from the above mentioned, results concerning the production of the plants suitable for marketing growing in 16 $\mathrm{cm}$ pot in the same age, in the type of tissue culture and those grown in the medium of sand + compost $15 \%$ and the terminal cutting grown in the medium of sand + compost $15 \%$ registering 0.89 and 2.33 (LE), respectively. So the type of propagation of tissue culture proved that it was the best economic method for plant production.

\section{REFERENCES}

Abdel-Sattar, M.M.; Ahmed, S.S. and Nabih, A. (2010). Response to tuberose (Polianthes tuberosa, L.) plant to $\mathrm{GA}_{3}$, treatment. Eygpt. J. Biotechnol., 35:149171.

Abou Dahab, A.M.; Habib, A.M.A.; Hosni, Y.A. and Gabr, A.M.M. (2005). Effect of MS-salt strength, sucrose and IBA concentration and acclimatization media on Ruscus hypoglossum L. micropropagation. Arab J. Biotech., 8(1):141-154.

Table 18. Effect of potting media on growth characters of $R$. equisetiformis ex vitro.

\begin{tabular}{lcccccccc}
\hline \multirow{4}{*}{ Potting media } & \multicolumn{8}{c}{ Growth parameters } \\
\cline { 2 - 9 } & $\begin{array}{c}\text { Survival } \\
\text { (\%) }\end{array}$ & $\begin{array}{c}\text { Plant } \\
\text { height } \\
\text { (cm) }\end{array}$ & $\begin{array}{c}\text { Branch } \\
\text { number/ } \\
\text { plant }\end{array}$ & $\begin{array}{c}\text { Root } \\
\text { length } \\
\text { (cm) }\end{array}$ & $\begin{array}{c}\text { Shoot f.w. } \\
\text { (g) }\end{array}$ & $\begin{array}{c}\text { Shoot } \\
\text { d.w. (g) }\end{array}$ & $\begin{array}{c}\text { Root f.w } \\
\text { (g) }\end{array}$ & $\begin{array}{c}\text { Root d.w } \\
\text { (g) }\end{array}$ \\
\hline Sand + compost 15\% & 89.86 a & 27.86 & 34.29 & 8.9 & 1.63 & 0.347 & 0.304 & 0.107 \\
Clay + sand (1:1) & $73.14 \mathrm{~b}$ & 28.79 & 39.43 & 7.66 & 1.83 & 0.368 & 0.284 & 0.0828 \\
L.S.D. & 10.89 & NS & NS & NS & NS & NS & NS & NS \\
\hline
\end{tabular}


Table 19. Cost of the in vitro propagation of $R$. equisetiformis through three successive subcultures according to the most favorable results of tissue culture trial.

\begin{tabular}{clccc}
\hline & Production element & Total amount & Unit price (LE) & Total price (LE) \\
\cline { 2 - 5 } & MS media & $1201(2.5$ bottle) & 250 & 625 \\
$\begin{array}{c}\text { Ansar } \\
\text { culture lab. }\end{array}$ & BAP & $1 \mathrm{~kg}$ & 400 & 400 \\
& Sugar & $70 \mathrm{mg}$ & 175 & 200 \\
& Electric energy & $3.6 \mathrm{~kg}$ & 10 & 36 \\
& Wages for worker & & & 3339 \\
& Total cost (LE) & & 100 & 4000 \\
& The seedling produced & & 8600 & \\
& Seedling cost (LE) & & & 25000 \\
\hline
\end{tabular}

Table 20. A feasibility study to compare propagation types of Russelia eqisetformis and growing media in field for six months.

\begin{tabular}{|c|c|c|c|c|c|c|c|c|}
\hline \multirow{2}{*}{$\begin{array}{c}\begin{array}{c}\text { Propagation } \\
\text { types }\end{array} \\
\text { Growing media }\end{array}$} & \multicolumn{2}{|c|}{ Terminal cutting } & \multicolumn{2}{|c|}{ Mid cutting } & \multicolumn{2}{|c|}{ Division parts } & \multicolumn{2}{|c|}{ Tissue culture } \\
\hline & $\begin{array}{c}\text { Sand + } \\
\text { clay } \\
(1: 1 v / v)\end{array}$ & $\begin{array}{c}\text { Sand + } \\
\text { compost } \\
15 \%\end{array}$ & $\begin{array}{c}\text { Sand }+ \\
\text { clay } \\
(1: 1 v / v)\end{array}$ & $\begin{array}{c}\text { Sand + } \\
\text { compost } \\
15 \%\end{array}$ & $\begin{array}{c}\text { Sand }+ \\
\text { clay } \\
(1: 1 v / v)\end{array}$ & $\begin{array}{c}\text { Sand + } \\
\text { compost } \\
15 \%\end{array}$ & $\begin{array}{c}\text { Sand }+ \\
\text { clay } \\
(1: 1 v / v)\end{array}$ & $\begin{array}{c}\text { Sand + } \\
\text { compost } \\
15 \% \\
\end{array}$ \\
\hline Cutting price & 50 & 50 & 50 & 50 & 275 & 275 & 9.18 & 9.18 \\
\hline Number of plant & 27 & 27 & 27 & 27 & 27 & 27 & 27 & 27 \\
\hline Clay price & 0.891 & -- & 0.891 & -- & 0.891 & - & 0.891 & -- \\
\hline Sand price & 1.35 & 2.295 & 0.135 & 2.295 & 1.35 & 2.295 & 1.35 & 1.35 \\
\hline Compost price & -- & 4.05 & -- & 4.05 & -- & 4.05 & -- & 4.05 \\
\hline Water price & 0.486 & 0.486 & 0.486 & 0.486 & 0.486 & 0.486 & 0.486 & 0.486 \\
\hline Cost worker & 6 & 6 & 6 & 6 & 6 & 6 & 6 & 6 \\
\hline Rent land & 0.75 & 0.75 & 0.75 & 0.75 & 0.75 & 0.75 & 0.75 & 0.75 \\
\hline Pot $16 \mathrm{~cm}$ price & 5.4 & 5.4 & 5.4 & 5.4 & 5.4 & 5.4 & 5.4 & 5.4 \\
\hline Fertilization & 0.0486 & 0.0486 & 0.0485 & 0.0486 & 0.0486 & 0.06486 & 0.0486 & 0.0486 \\
\hline $\begin{array}{l}\text { Total cost } \\
\text { (LE) }\end{array}$ & 64.84 & 63.01 & 63.71 & 69.03 & 290.00 & 294.00 & 24.10 & 27.25 \\
\hline $\begin{array}{l}\text { Cost per plant } \\
\text { (LE) }\end{array}$ & 2.40 & 2.33 & 2.36 & 2.55 & 10.74 & 10.88 & 0.89 & 1.00 \\
\hline Pot for sell (LE) & 12 & 12 & 12 & 12 & 15 & 15 & 10 & 10 \\
\hline $\begin{array}{c}\text { Survival of } \\
\text { plant }\end{array}$ & 22 & 23 & 21 & 21 & 24 & 25 & 18 & 24 \\
\hline Total revenue & 264.0 & 276.00 & 252.00 & 252.00 & 360.00 & 375.00 & 180.00 & 240.00 \\
\hline Net return (LE) & 199.16 & 212.99 & 188.92 & 182.97 & 70.00 & 81.00 & 155.90 & 212.75 \\
\hline $\begin{array}{c}\text { Profitability rate } \\
\% \\
\end{array}$ & 307.15 & 338.2 & 296.53 & 265.05 & 24.13 & 21.60 & 646.88 & 780.73 \\
\hline
\end{tabular}

Total revenue $=$ number of pots maturity $\times$ price unite $\&$ Net return $=$ total revenue $\times$ total cost. Profitability rate $=($ net return $/$ total cost $) \times 100$. 
Abou Dahab, A.M.; Habib, A.M.A.; Hosni, Y.A. and Gabr, A.M.M. (2005). Effect of MS-salt strength, sucrose and IBA concentration and acclimatization media on Ruscus hypoglossum L. micropropagation. Arab J. Biotech., 8(1):141-154.

Al-Ashry, A.; Nabih, A. and Ibrahim, C.A. (1998). Influence of growing media, planting condition and planting dates on rooting, growth and chemical constituents of Dracaena reflexa, L. Egypt. J. Appl. Sci., 13 (12):187-227.

Ameeta, S. and Agrawal, M. (2012). Tissue culture aspects of ornamental plants. IB Tech J. of Biotechnology An Online International Journal, 1(1):40-48.

Askar, F.A. (1988). Suitability of soil conditioners for desert and cultivated soil in Egypt. Proc. Inter. Soil Conditioners, Egypt, pp. 133-142.

Bredmoie, N. and Hansen, J. (1996). Topophysis affects the potential of auxiliary bud growth, fresh biomass accumulation and specific fresh weight in single-stem roses (Rosa hybrid, L.). Annals of Botany, 78:215-222.

Corchete, M.P.; Fenning, T.; Gartcand, L.S. and Valle, T. (1997). Micropropagation of Ulmus species (Elms). In Biotechnology in Agriculture and Forestry. 39. High-Tech and Micropropagation V (Bajaj, Y. P. S., ed.), p. 381-392. Springer-Verlag, BerlinHeidelberg.

De Andres, E.F.; Alegre, J.; Tenorio, J.L.; Manzanares, M.; Sanchez, F.J. and Ayerbe, L. (1999).Vegetative propagation of Colutea arborescens L., a multipurpose leguminous shrub of semiarid climates. Agroforestry Systems, 46:113-118.

Debnath, S.C. (2004). Clonal propagation of dwarf raspberry (Rubus pubescens Raf.) through in vitro axillary shoot proliferation. Plant Growth Regulation, 43:179-186.
El-Shewikh, Y.M. (2000). Effect of Mineral Nutrition, Planting Media and Size of Pots on Brunfelisia caycina, L. Plants. Ph.D. Thesis, Fac. Agric., Cairo Univ., Egypt, 128 p.

Evaldsson, I.E. and Welander, N.T. (1985). The effects of medium composition on in vitro propagation and in vitro growth of Cordyline terminalis cv. Atoom. J. Hort. Sci., 60:525-530.

Floyed, C.A. (1965). Raising and planting out of black out in jiffy pots for corm. Tech. p. No. 9.

Garas, E.A. (2011). Effect of Growing Media, Irrigation Rates and Grafting on Growth and Flowering of Hibiscus spp. plants. Ph.D. Thesis, Fac. Agric., Cairo Univ., Egypt, 306 p.

Gomma, S.A. (2000). Physiological Studies on Polianthes tuberose and Orithogalum thrysoildes Bulbs. Ph.D. Thesis, Fac. Agric., Kafr El-Sheikh Tanta Univ.

Govil, S. and Gupta, S. (1997). Commercialization of plant tissue culture in India. Plant Cell, Tissue and Organ Culture. 51:65-73.

Gregory, J.B. (2013). Growth of ornamental plant in container media Amended with biosoilds compost. Compost Science \& Utilization, 10(2):92-98.

Hall, N.J. and Richmond, K.P. (1968). Raising eucalypto in posts. Aust. For., 23:46-48.

Hamad, A.M. and Taha, R.M. (2008). Effect of sequential subcultures on in vitro proliferation capacity and shoot formation pattern of pineapple (Ananas comosus L. Merr.) over different incubation periods. Sci. Horticulturae, 117:329-334.

Ibrahim, C.A.; Nabih, A. and El-Malt, A.A. (1998). Effects of planting conditions and growing media on rooting, growth and chemical constituents of Monstera deliciosa, L. Egypt. J. Appl. Sci., 13(9):155-184. 
Internet Site 1: https://en.wikipedia.org/ wiki/Russelia_equisetiformis.

Internet Site 2: http:/www.dgsgardpningttinternet.co.uk/soil htm.

Islam, S.; Jahan, M.A.A. and Khatun, R. (2005). In vitro regeneration and multiplication of year_round fruit bearing Moringaoleifera L. J. Biol. Sci., 5:145148.

Lichtenthaler, H.K. and Wellburn, A.R. (1985). Determination of total carotenoids and chlorophylls A and B of Leaf in different solvents. Biol. Soc. Trans., 11:591-592.

Montarone, M.; Savignac, D. and Bearez, P. (1997). Effect of the position of cuttings along the mother stem on the rhizogenesis and the ramification in soilless cultivation. Acta Hortic., 453:8798.

Murashige, T. and Skoog, F. (1962). A revised medium for rapid growth and bioassays with tobacco tissue cultures. Physiologya Plantarum, 15:473-497.

Norton, M.E. and Norton, C.R. (1986). Change in shoot proliferation with repeated in vitro subculture of shoots of woody species of Rosaceae. Plant Cell Tissue and Organ Culturae, 5:187-197.

Obreza, T.A. and Azores, H.M. (2000). Management of organic amendments in Florida Citrus production systems. Proceeding Soil and Crop Sci. Soc. Florida, 59:22-27.

Ochoa, J.; Bañón, S.; Fernández, J.A.; González, A. and Franco, J.A. (2003). Influence of cutting position and rooting media on rhizogenesis in oleander cuttings. Acta Hortic., 608:101-106.

Ozores-Hampton, M.; Obreza, T.A. and Hochmuth, G. (1998). Using composted wastes on Florida vegetables crops. HortTechnology, 8(2):130-137.

Polisetty, R.; Patil, P.; Deveshwar, J.J.; Khetarpal, S. and Chandra, R. (1996). Rooting and establishment of in vitro grown shoot tip explants of chickpea (Cicer arietinumL.). Ind. J. Exp. Biol., 34(8):806-809.

Rathore, J.S.; Rathore, V.; Shekhawat, N.S.; Singh, R.P.; Liler, G.; Phulwaria, M. and Dagla, H.R. (2004). Micropropagation of woody plants. In: Srivastava, P.S.; Narula, A. and Srivastava, S. (eds), Plant Biotechnology and Molecular Markers. New Delhi, Anamaya Publishers: 195205.

Remphrey, W.R.; Palmer, C.E. and Blouw, M.J. (1993). In vitro branching in relation to repeated subculture in two cultivars of Potentilla fruticosa. Plant Cell Tissue and Organ Culture, 32:235-240.

Riyathong, T.; Dheeranupattana, S.; Palee, J. and Shank, L. (2010). Shoot Multiplication and plant regeneration from in vitro cultures of drumstick tree (Moringa oleiferaLam.). Proc. The $8^{\text {th }}$ International Symposium on Biocontrol and Biotechnology, October, 4-6 Pattaya, Thailand. 99-104.

Sakr, S.S.; El-Khateeb, M.A. and Abd-ElKareim, A.H. (1999). In vitro production of Yucca elephantips. Bull. Fac. Agric., Univ. Cairo, 50(2):265-282.

SAS program (1995). SAS ITAT User's Guide; Statistics. Vers. 6. $044^{\text {th }}$ ED, SAS Institute Inc. Cary. N.C., U.S.A.

Sayed, S.S.; Abou-Dahab, T.A. and Youssef, E.M.A. (2005). In vitro propagation of cactus (Cereus peruvianu.Arab. J. Biotech., 8(1):169-176.

Shanks, J. and Gouin, F. (1985). Using compost in the root rosesal. Biocycle, 25:29-31.

Shekhawat, M.S. and Manokari, M. (2015). Micropropagation of Russelia equisetiformis Schlecht\& Cham. through nodal segment culture. World Scientific News, 2:117-127.

Singh, C.R. and Nair, S.A. (2003). Standardzation of rooting media for 
cuttings of certain house plants. J. Ornamental Hort., 6(1):78-79.

Snedecor, G.W. and Cochran W.G. (1990). Statistical Methods. $11^{\text {th }}$ Ed. Iowa State Univ., Press. Ames, Iowa, U.S.A.

Teklehaimanot, Z.; Mwang, P.L.; Mugasha, A.G. and Ruffo, C.K. (2004). Influence of the origin of stem cutting, season of collection and auxin application on the vegetative propagation of African Sandalwood (Osyris lanceolata) in Tanzania. Southern African Forestry J., 201(1):13-24.

Trigiano, R.N. and Gra, D.J. (2000). Plant Tissue Culture Concepts and Laboratory Exercises, Second Edition. P: 80, CRC Press LLC Boca Raton, FL.

Troy, S.H. and Paul, F.H. (2001). Effects of compost on loblolly pine tree growth in
Northeast Texas. Compost Science \& Utilization, 9(1):65-72.

Varjda, R. and Varjda, T. (2001). The effect of cytokinin type and concentration and number of subcultures on the multiplication rate of some decorative plants. Proceedings of the Estonian Academy of Sci., Biology and Ecology, 50:22-32.

Wallace, A. and Wallace, C.A. (1990). Interaction between polymer soil conditioners and organic in the improvement of physical properties of soil. J. P. Nutrit, 13(3-4):437-450.

Wong, W.C. (1986). In vitro propagation of banana (Musa spp.): Initiation, proliferation and development of shoottip cultures on defined media. Plant Cell Tiss. Organ Cult., 6:159-166.

\section{الجدوى الإقتصادية للإكثثار الحقلى والدقيق لنبات الروسيليا}

$$
\begin{aligned}
& \text { محمد سالم مشعل ، خالد عبد المحسن إمام إبر اهيم **، فوزيه زينة غارب ** و إيفون عاطف خلة جرس **** }
\end{aligned}
$$

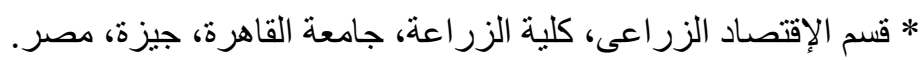

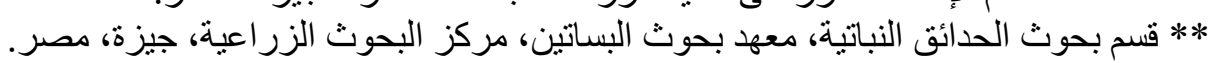

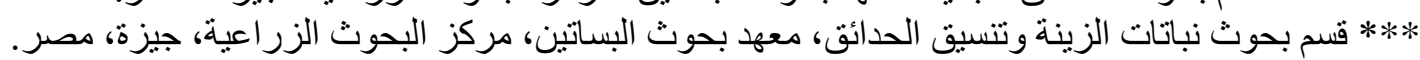

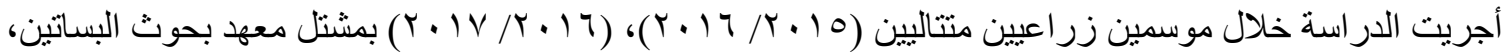

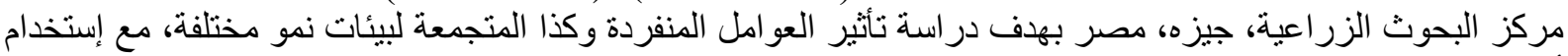

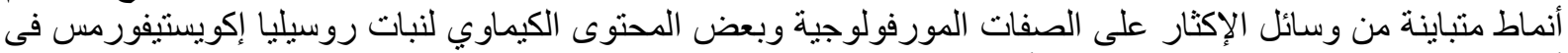

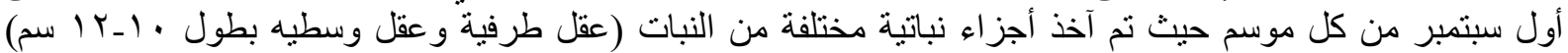

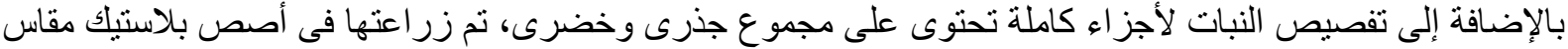

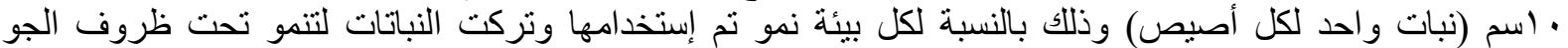

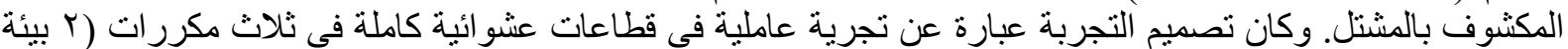

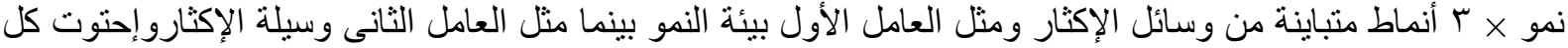

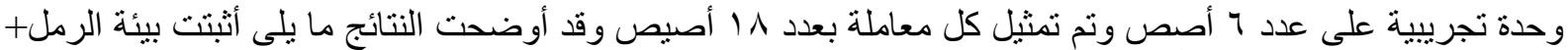

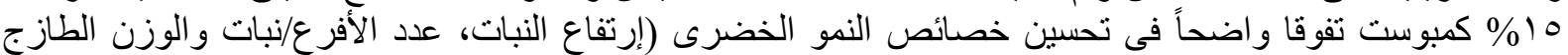

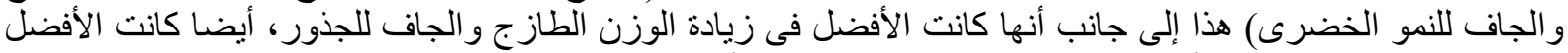

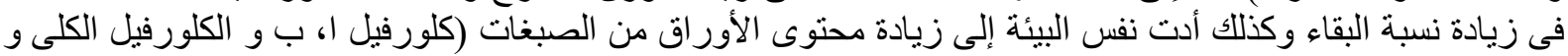

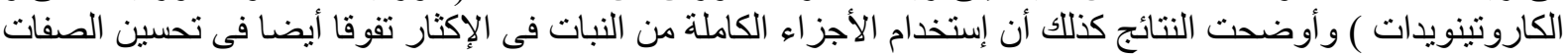
الموفولوجية السابق دكر ها فى كلا المون الموسمين. وقد أظهرت النتائج أن إستخدام العقل الطرفية تفوق تفوقات التوان واضحا في زيادة النسبة المئوية للبقاء بينما كان لإستخدام

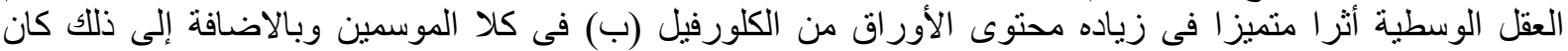

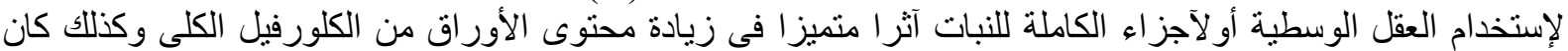

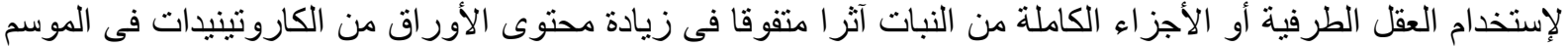

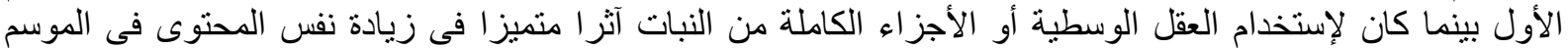


من النتائج السابقة و التفاعلات يمكن النصح بإستخدام الأجزاء الكاملة من النبات مع إستخدام مخلوط الرمل

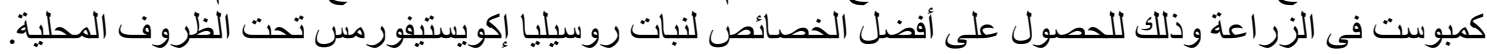

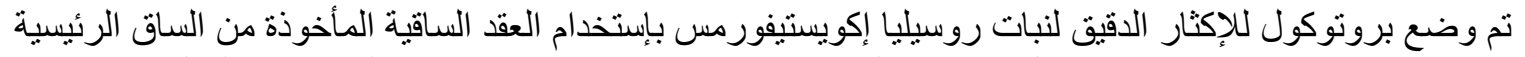

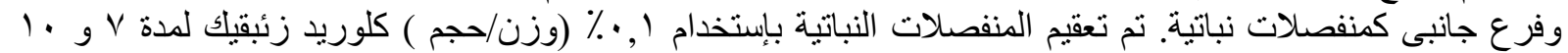

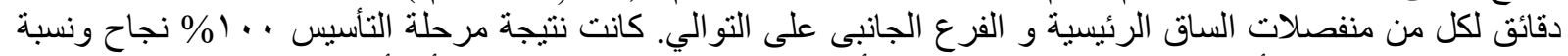

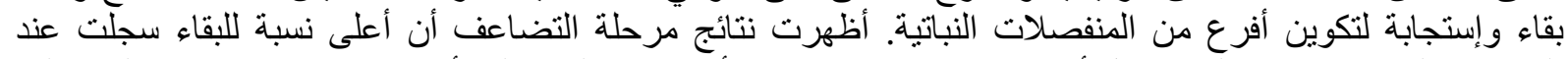

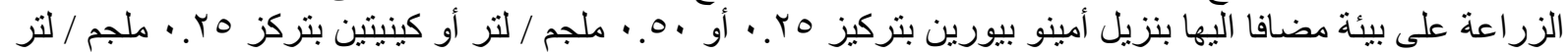

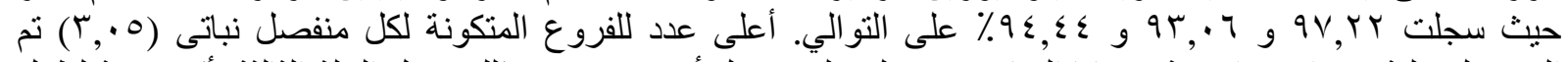

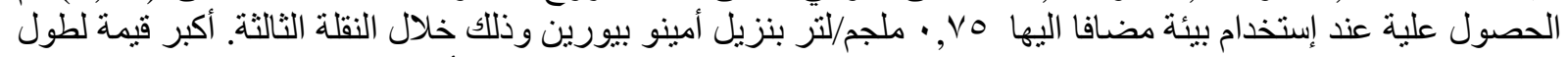

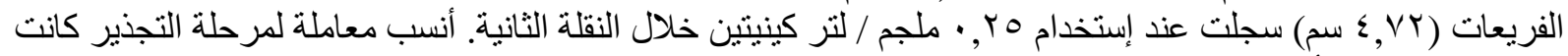

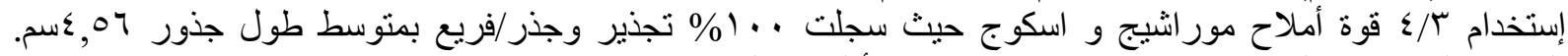

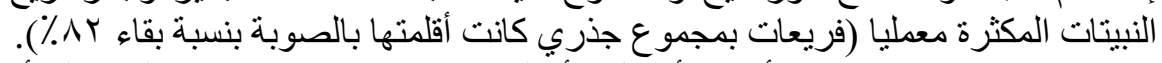

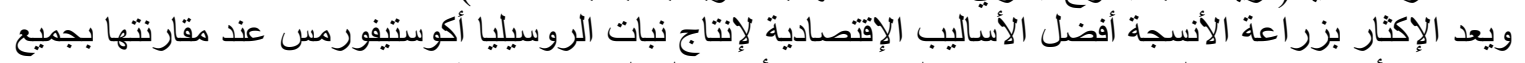

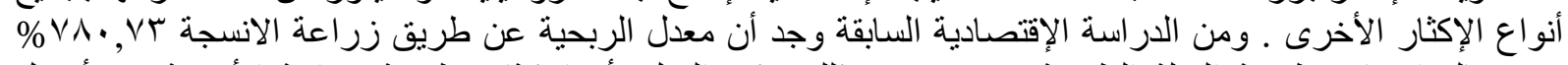

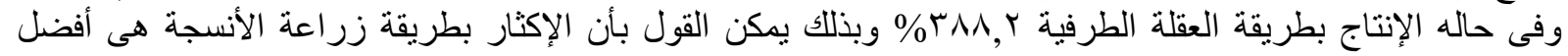

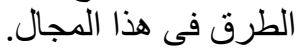




